\title{
A case of intersex occurrence in Steindachneridion parahybae (Steindachner, 1877) (Siluriformes: Pimelodidae) under captivity condition: a cytogenetic and morphological study
}

\author{
Renato M. Honji $1^{1}$, Danilo Caneppele ${ }^{2}$, Matias Pandolfi ${ }^{3}$, Fabiana L. Lo Nostro ${ }^{3}$ and \\ Renata G. Moreira ${ }^{1}$
}

Little is known about reproductive biology of endangered Steindachneridion parahybae, a gonochoristic teleost species inhabiting the Paraíba do Sul River Basin, and herein is the first description of intersex in S. parahybae juvenile. The normal appearance of ovaries and testes in juvenile from the same lot of breeding were also described for comparison, even as cytogenetic analysis was performed in these juveniles. One specimen was a priori classified as female due to the macroscopic characteristic of ovaries, with small yellow oocytes, without fringes (a main characteristic of catfish male), and larger than testes; however the microscopic analysis revealed the presence of ovotestes, including the complete spermatogenesis. $S$. parahybae had diploid number, $2 \mathrm{n}=56$ chromosomes with no evidence of differentiated sex chromosomes or supernumerary chromosomes among them. These findings may be due to the result of exposure to endocrine disrupting compounds or may also be influenced by environmental conditions. The possibility of intersexes might also happen spontaneously and it cannot be ruled out. Therefore, the functional significance and reproductive consequences of this anomaly remain to be determined, suggesting that this species may be susceptible to endocrine disruption. These results contribute to gain expertise about reproductive biology of an endangered species in captivity.

Poco se sabe sobre la biología reproductiva de Steindachneridion parahybae, una especie de teleósteo gonocorístico en peligro de extinción que habita la cuenca del río Paraíba do Sul y en éste trabajo se describe por primera vez la aparición de individuo intersexo en juvenil de $S$. parahybae. También se describió el aspecto normal de los ovarios y de los testículos de individuos juveniles procedentes del mismo lote de cría para su comparación; se realizó además el análisis citogenético. Un espécimen fue clasificado a priori como hembra debido a las características macroscópicas de los ovarios, con pequeños oocitos amarillos, sin flecos (característica principal de los bagres macho) y más grande que los testículos; sin embargo el análisis microscópico reveló la presencia de un ovotestis, incluyendo una espermatogénesis completa. $S$. parahybae presentó un número diploide, $2 \mathrm{n}$ $=56$ cromosomas, sin evidencia de cromosomas sexuales diferenciados o supernumerarios entre ellos. Estos hallazgos pueden deberse al resultado de la exposición de los individuos a desorganizadores endocrinos o estar influenciados por las condiciones ambientales. Sin embargo no se puede descartar la posibilidad de la presencia de intersexos de forma espontánea. Por lo tanto, la importancia funcional y las consecuencias reproductivas de estas anomalías permanecen aún sin ser determinadas, sugiriendo que esta especie puede ser susceptible a los disruptores endocrinos. Estos resultados contribuyen a ampliar el conocimiento de la biología reproductiva de esta especie en peligro de extinción en condiciones de cautiverio.

Keywords: Histology, Karyotype, Ovary, Ovotestes, Testicles.

\section{Introduction}

As shown by Nelson (2006) fishes are the speciesrichest group among vertebrates, comprising slightly more than one-half of the number of vertebrate species $(54,711)$ known to date. They present a notable level of diversity at all the biological levels of organization, which affect their morphology, physiology, behavior, ecology and genomes, as well as multiple other aspects of their biology (Volff, 2005). With respect to sex determination and sex differentiation in fish, almost every mechanism that is possible is represented in this vertebrate group (see Devlin

\footnotetext{
${ }^{1}$ Departamento de Fisiologia, Instituto de Biociências, Universidade de São Paulo. Rua do Matão, Travessa 14, 321, 05508-090 São Paulo, SP, Brazil. (RMH) honjijp@usp.br (corresponding author), (RGM) renatagm@ib.usp.br

${ }^{2}$ Companhia Energética de São Paulo (CESP), Unidade de Hidrobiologia e Aquicultura. Rodovia dos Tamoios, km 38, $12260-000$ São Paulo, SP, Brazil. (DC) danilo.caneppele@cesp.com.br

${ }^{3}$ Departamento de Biodiversidad y Biología Experimental, Facultad de Ciencias Exactas y Naturales, Universidad de Buenos Aires \& IBBEA, CONICET-UBA. Ciudad Universitaria (C1428EHA), Buenos Aires, Argentina. (MP) pandolfi@bg.fcen.uba.ar, (FLLN) fabi@bg.fcen.uba.ar
} 
\& Nagahama, 2002 for a review on sex determination and sex differentiation in fish). Sex determination is primarily under genetic control but may also be influenced by environmental conditions (Strüssmann \& Nakamura, 2002). About genetic control, teleost fish species represents a heterogeneous group and presenting eight systems of sex determination controlled by sex chromosomes (Devlin \& Nagahama, 2002). Therefore, cytogenetics studies are used as important tools for the understanding of different aspects such as sex determination mechanisms or sex differentiation process, sex chromosomes evolution, existence of supernumerary chromosomes, among other researches (Pisano et al., 2007).

Many teleost are gonochorists, in which animals develop only as females or males, and remain the same sex throughout their lifetime (Devlin \& Nagahama, 2002). Other in turn, they are considered as hermaphrodite teleosts, where one individual can produce mature female and male gametes at some time in their lives. This includes sequential hermaphrodites; classified as protogynous (first mature as females) or as protandrous (first mature as males); or as synchronous hermaphrodites, where individuals can develop female and male gametes at the same time (Devlin \& Nagahama, 2002). According to Tyler \& Jobling (2008), the intersexuality is a disorder defined as a simultaneous occurrence of both female and male gonadal tissue within the same individual of a gonochoristic species. Therefore, intersex disorder should not be confused with natural hermaphroditism. This condition is also referred to the presence of testicular oocytes, testicular follicles, testisova, or ovotestes (Bahamonde et al., 2013), and it has been reported in several teleost species (Devlin \& Nagahama, 2002; Godwin, 2010). However, there is no exact causation of intersex and currently under investigation.

Intersexes occurrences in natural populations of fish were few and referred generally to some individuals, suggesting that intersex disorder in natural gonochoristic fishes were rare event (Nolan et al., 2001). On the other hand, over the last couple of years, in various wild populations of these gonochoristic teleosts increased the prevalence of intersex and it has been identified worldwide and associated with the presence of natural and synthetic endocrine disrupting chemicals (EDCs), such as hormones, its metabolites or chemical pollutants, which reaching aquatic ecosystems with effluents of various origins (Bahamonde et al., 2013). Therewithal, the effects of raising global temperature and unforeseen climatic changes on natural fishery resources may also be linked to the increase of this disorder (Strüssmann \& Nakamura, 2002; Bahamonde et al., 2013). Although this association of intersex occurrence with EDCs and/or global temperature, questions remain concerning the prevalence of intersex in wild fish populations and how this might be related to the molecular process events underlying sex determination and/or sex differentiation, and it is a widely discussed topic globally (Nolan et al., 2001; Bahamonde et al., 2013).
Nowadays, aquaculture continues to be the fastestgrowing animal food-producing sector, and the number of teleost species currently under domestication efforts is increasing due to the development of marketable aquaculture (FAO, 2010; Mylonas et al., 2010). Hormonal therapies can be employed to induce sex reversal and may serve to monosex production in fisheries management, because in some fish species the males grow faster than females or males are more colorful than females, and thus have a higher commercial value (Pandian \& Sheela, 1995). Monosex populations are produced by exposure of new hatched to natural or synthetic hormones, such as oestrogens or androgens (Beardmore et al., 2001). On the other hand, as treatment intensities for endocrine sex reversal are increasing, a known percentage of intersex in fish rearing to aquaculture is increasing too (Pandian \& Sheela, 1995). Additionally, a new vision for aquaculture activity has gradually emerged from numerous studies, by applying it to the conservation of endangered fish species (Honji et al., 2015).

Paraíba do Sul River Basin is an isolated hydrographic basin (20'26' and $23^{\circ} 39^{\prime} \mathrm{S}$ and $41^{\circ} 00^{\prime}$ and $\left.46^{\circ} 30^{\prime} \mathrm{W}\right)$ and is considered one of the largest floodplain basin located in the Southeast Brazil. Despite being an important basin in this region, encompass an area with uppermost level of urban and industrial development, which causes great impact in the life cycle of the animals (Hilsdorf \& Petrere Jr, 2002). Currently, this basin has been suffering with anthropogenic disturbances, such as intensive agriculture (coffee, greens, flowers and eucalyptus), domestic and industrial pollution, and river disruption by dam construction, which contributed to the decline and the impairment of local ichthyofauna (Hilsdorf \& Petrere Jr, 2002; Caneppele, 2007; Honji et al., 2009). Over the last couple of years, a conservation action in this basin has been taking place involving a fish restocking program run by Companhia Energética de São Paulo (CESP), which has supported biological researches of the main native fish species of the Paraíba do Sul River Basin (CESP, 2006a). These studies, such as the maintenance and genetic management of broodstocks, successful larval rearing, ensure effective controlled breeding technology, it has been performed on a few fish populations that still remain in northern tributaries and/or in captivity (fish farm conservation)

The Neotropical catfish Steindachneridion parahybae is a gonochoristic medium-sized siluriform species, an important migratory (potamodromous), ichthyophagous freshwater fish, endemic to the Paraíba do Sul River Basin (Garavello, 2005), seriously endangered in this basin and regionally extinct in São Paulo State (Honji et al., 2009). The scarce biological information of $S$. parahybae and the critically endangered situation highlight the importance of increasing the knowledge about the reproductive biology in this species under captivity condition, since any new insights into your biology can be applied in fish farming aimed to conservation. Meanwhile since 2003, CESP has supported 
researches on the basic biology studies of $S$. parahybae (CESP, 2006b), and more recently this species was also included in the Research Program on Global Climate Change, funded by a Brazilian Governmental Program (Fundação de Amparo à Pesquisa do Estado de São Paulo), about "Effects of global climate change of the Brazilian fauna: a conservation physiology approach" (Navas, 2008).

As presented here, there is little information on the $S$. parahybae reproductive biology. Therefore, the aim of this study was to describe in detail the intersex occurrence in $S$. parahybae, using macroscopic and microscopic analysis of the gonads from juvenile that were raised in captivity at fish farm from parental originating of wild broodstocks. The normal appearance of the ovaries and testes in S. parahybae juveniles from the same lot of breeding was also described for comparison. Additionally, traditional cytogenetic techniques were also performed in these animals (females, males and intersex specimens) with the aim of contributing toward the karyotypic data description and genetic control of sex determination in this endangered fish species.

\section{Material and Methods}

Animals. Wild $S$. parahybae broodstocks were captured from Paraíba do Sul River, near to town of Rio das Flores in the Rio de Janeiro State, Brazil (22 ${ }^{\circ} 13^{\prime} 54^{\prime \prime} \mathrm{S}$ and $43^{\circ} 25^{\prime} 15^{\prime \prime} \mathrm{W}$ ), transferred to Hydrobiology and Aquaculture Unit of the CESP, located in Paraibuna city,

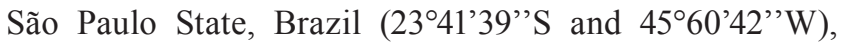
and rearing to artificial induced spawning. Descriptions of the fishing gear, catch operations and induced spawning of these wild broodstocks were followed in accordance with Caneppele et al. (2009) and Honji et al. (2012a). It's important make sure that, this study is also associated with the project "Environmental influences on the mechanisms of sex determination and differentiation in teleost fish", undertaken by Honji (2011b) whose main aim is to analyze the possibility that thermmolabile sex determination and/ or sex differentiation in teleost fish (including specially the S. parahybae).

We used 10 juveniles (with approximately one year of age, Table 1) of $S$. parahybae raised in captivity at the CESP fish farm from parental originating of wild broodstocks. In December 2012, the raised animals randomly sampled in the CESP fish farm were transported to the Laboratório de Metabolismo e Reprodução de Organismos Aquáticos (LAMEROA) of the Instituto de Biociências (Universidade de São Paulo, Brazil), and housed in individual tanks (130 1) with closed water recirculation system, under conditions mimicking their natural habitat: brown walls, $23 \pm 2^{\circ} \mathrm{C}$ and 14:10 light:dark cycle (Caneppele et al., 2009; Honji et al., 2009), and with constant aeration. Every morning, we fed fish with commercial extruded feed for carnivorous fish $\left(40 \%\right.$ crude protein, Purina $\left.{ }^{\circledR}\right)$ at the rate of $2 \%$ of the biomass/day. The animals were allowed to acclimate to aquaria conditions for at least three weeks before their incorporation into the cytogenetic, macroscopic and microscopic analyses of the gonads. Furthermore, the experimental design was conducted in accordance with international standards on animal welfare, as well as we took appropriate actions to minimize pain and discomfort of the animals.

For cytogenetic, macroscopic and microscopic analyses of the gonads, the fish were anesthetized with $0.1 \%$ benzocaine (ethyl-p-aminobenzoate), total and standard length $(\mathrm{cm})$ and total body weight $(\mathrm{g})$ were registered for each animal (Table 1), and then fish were killed by decapitation at the level of the operculum. A priori the macroscopic identification of the gonads was classified by the naked eye, using the Honji et al. (2013) macroscopic characterization of adult $S$. parahybae gonads. After this procedure, gonads and liver were removed and weighed on analytical balance, accurate to the nearest thousandth of a gram (g), for calculate the gonadosomatic and hepatosomatic index and then, the middle third of the gonads were fixed in Bouin's solution for $24 \mathrm{~h}$ to confirm the sex for histological analysis. Anterior kidney was also quickly removed for cytogenetic analysis.

The procedures to sacrificed animals used in this study are in agreement with the Animal Ethics Committee of the Instituto de Biociências, Universidade de São Paulo, Brazil (Protocol 072/2008). Furthermore, S. parahybae specimen's vouchers, chromosomes preparations and histological slides were deposited in the collection of the LAMEROA.

Gonadosomatic and hepatosomatic index and histological analysis of the gonads. Both, the gonadosomatic (GSI) index (Vazzoler, 1981, 1996), which is expressed as the percentage of body weight in relation to the gonads [GSI = (gonads weight/total weight) $x$ 100] and the hepatosomatic (HSI) index (Vazzoler, 1981, 1996), which is the percentage of body weight represented by the liver [HSI = (liver weight/ total weight) X 100], were calculated for all animals.

The fixed gonads were dehydrated through a series of increasing ethanol concentrations, and then cleared in dimethylbenzene solution and embedded in Paraplast ${ }^{\circledR}$ (ErvPlast; Erviegas Instrumental Cirúrgico, São Paulo, Brazil) according to routine histological procedures (Behmer et al., 1976). For better details of the gonadal development, other pieces of the fixed gonads were dehydrated in ethanol and embedded in Historesin ${ }^{\circledR}$ (Leica Historesin Embedding Kit). Gonads sections (3 or $5 \mu \mathrm{m}$ thick) were obtained, mounted on Poly-L-Lysine (Sigma-Aldrich Diagnostics INS, St. Louis M.O. USA) solution-coated slides, and stained with Haematoxylin/Eosin (Behmer et al., 1976) or PeriodicAcid-Schiff(PAS)/Weigert's Haematoxylin/Metanil Yellow (Quintero-Hunter et al., 1991). Morphological details wellpreserved in aldehyde fixed gonads processed through glycol methacrylate are enhanced with this modified PAS staining. Furthermore, the PAS method (Pearse, 1985) or associated to other dyes (Quintero-Hunter et al., 1991) was used to detected neutral polysaccharides, which are magenta stained (França et al., 2010). 
Table 1. Data on Steindachneridion parahybae juvenile's biometrical parameters and gonadosomatic (GSI) and hepatosomatic (HSI) indexes at the Hydrobiology and Aquaculture Unit of Companhia Energética de São Paulo (CESP). Data are presented as the mean \pm Standard error of the mean $(\mathrm{M} \pm \mathrm{SEM})$. Values followed by different letters $(\mathrm{a}, \mathrm{b})$ are significantly different between sex (females or males) $(\mathrm{P}<0.05)$.

\begin{tabular}{lcccccc}
\hline Animal & $\mathrm{n}$ & Total length $(\mathrm{cm})$ & Total weight $(\mathrm{g})$ & Gonads weight $(\mathrm{g})$ & GSI $(\%)$ & HSI $(\%)$ \\
\hline Females & 3 & $17.70 \pm 1.11$ & $39.02 \pm 1.41^{\mathrm{a}}$ & $10.68 \pm 0.38^{\mathrm{a}}$ & $27.36 \pm 0.20^{\mathrm{a}}$ & $1.42 \pm 0.03$ \\
Males & 6 & $17.23 \pm 0.15$ & $44.18 \pm 0.18^{\mathrm{b}}$ & $1.21 \pm 0.06^{\mathrm{b}}$ & $2.73 \pm 0.13^{\mathrm{b}}$ & $1.23 \pm 0.10$ \\
Intersex & 1 & 17.40 & 44.80 & 12.67 & 28.28 & 1.54 \\
\hline
\end{tabular}

After staining, the sections were mounted with ErvMount ${ }^{\circledR}$ (Erviegas Instrumental Cirúrgico) and then examined under an optical microscope (Leica DM1000). Images were captured by a Leica photographic camera (DFC295) using the image capture Leica Application Suite Professional software (LAS V3.6).

Chromosome preparations and conventional staining. The mitotic chromosomes preparations were obtained from anterior kidney cells using Hank's solution for colchicine (Sigma-Aldrich Diagnostics INS) application, attempting to get better control of the action of the colchicine activity in vitro (procedure adapted from Gold et al., 1990) for fish studies, and the metaphases were stained by Giemsa. The chromosomal preparations were analyzed using a computerized image analysis (described above). The classification of chromosomal types was based on the arm ratio (Levan et al., 1964), and the fundamental number was calculated taking into account the fact that metacentric (m), submetacentric (sm) and subtelocentric (st) chromosomes are two-armed and acrocentric (a) elements are one-armed. Approximately 15 karyotypes for each fish were analyzed for Giemsa staining.

Statistical analyses. Statistical analysis of data related to morphometric analysis, GSI and HSI index, taking into account the sex (females or males) was performed using one-way analysis of variance (ANOVA), followed by Student-NewmanKeuls (SNK) or Tukey's test (Zar, 2010). A 95\% confidence level was applied to all statistical procedures $(\mathrm{P}<0.05)$. Additionally, data were expressed as mean \pm standard error of the mean (M \pm SEM). All statistical analyses were performed using the statistical software SigmaStat for Windows (version 3.10).

\section{Results}

Gonadosomatic and hepatosomatic index and histological analysis of the gonads. Steindachneridion parahybae gonads are paired and elongate organs, dorsally situated in the coelomic cavity, connected to the natatory bladder at the cranial portion and to the kidneys at the caudal portion. Lobes are joined posteriorly to form a short gonoduct that was opened to the outside through the urogenital pore. Macroscopically S. parahybae ovaries showed small yellow oocytes and they were larger than the testes (Table 1). Males have testes with surface fringes of different sizes and shapes over the entire surface area and presented white color. Additionally, among all animals sampled, one specimen was a priori classified as females, due to the macroscopic characteristic of ovaries, with small yellow oocytes, without fringes, and larger than the testes (Table 1). However under microscopic analysis different germ cells types, typical of testes, were observed including the complete process of spermatogenesis. This animal was referred to as "intersex animal" (IA).

Although no differences were observed in total length between males and females $(P=0.418)$, the males were heavier than females $(\mathrm{P}=0.010)$ (Table 1). On the other hand, the ovaries were heavier than testes $(\mathrm{P}<0.01)$ and this difference was reflected in GSI values $(\mathrm{P}<0.001)$ (Table 1). Additionally, no difference was observed in HSI values ( $\mathrm{P}=$ 0.156 ) between males and females (Table 1). The "IA" showed morphometric data, GSI and HSI index values similar to female's data (Table 1).

Based on the analysis of the histological cross sections of the $S$. parahybae juvenile ovaries, the following germ cell types and stages of oocyte development were identified (Fig. 1). They were described succeeding the development sequence of the oogenesis and folliculogenesis. The $S$. parahybae cystovarian type has numerous lamellae that project into the ovarian lumen; this lamellar surface in the cystovarian ovaries of this catfish is covered by the germinal epithelium (GE). GE is composed by somatic cells -the epithelial cells- and germ cells - the gonia- precursors of all germ cells (Fig. 1a).

Single oogonia has an ovoid form, small size, slightly basophilic nucleus and a clear cytoplasm and they are surrounded by prefollicle cells (Fig. 1a); proliferation of an oogonia gives rise to a cell cluster (the oogonia cell nests, Fig. 1b). Oogonia in the same clusters simultaneously enter into meiosis and then, progressively individualized by cells derived from the epithelium (prefollicle cells), at the time of meiotic arrest, the formation of the ovarian follicle occurred, and they become separated from the nests (Fig. 1c). Following the ovarian development, the oocyte in the early primary growth (or previtellogenic oocyte) (Fig. 1d) is characterized by an enhancement of a basophilic cytoplasm; nucleolar amplification results in production of multiple nucleoli, which are displaced in a perinuclear position (perinucleolar oocyte or perinucleolar phase of primary growth, Fig. 1d), and the thin cell layer surrounding the oocyte was also identified in this phase (Fig. 1e). Perinucleolar oocytes in different size were identified in these juveniles (Fig. 1f). In the present study, only these two germ cell types were easily identified in the $S$. parahybae ovaries. 

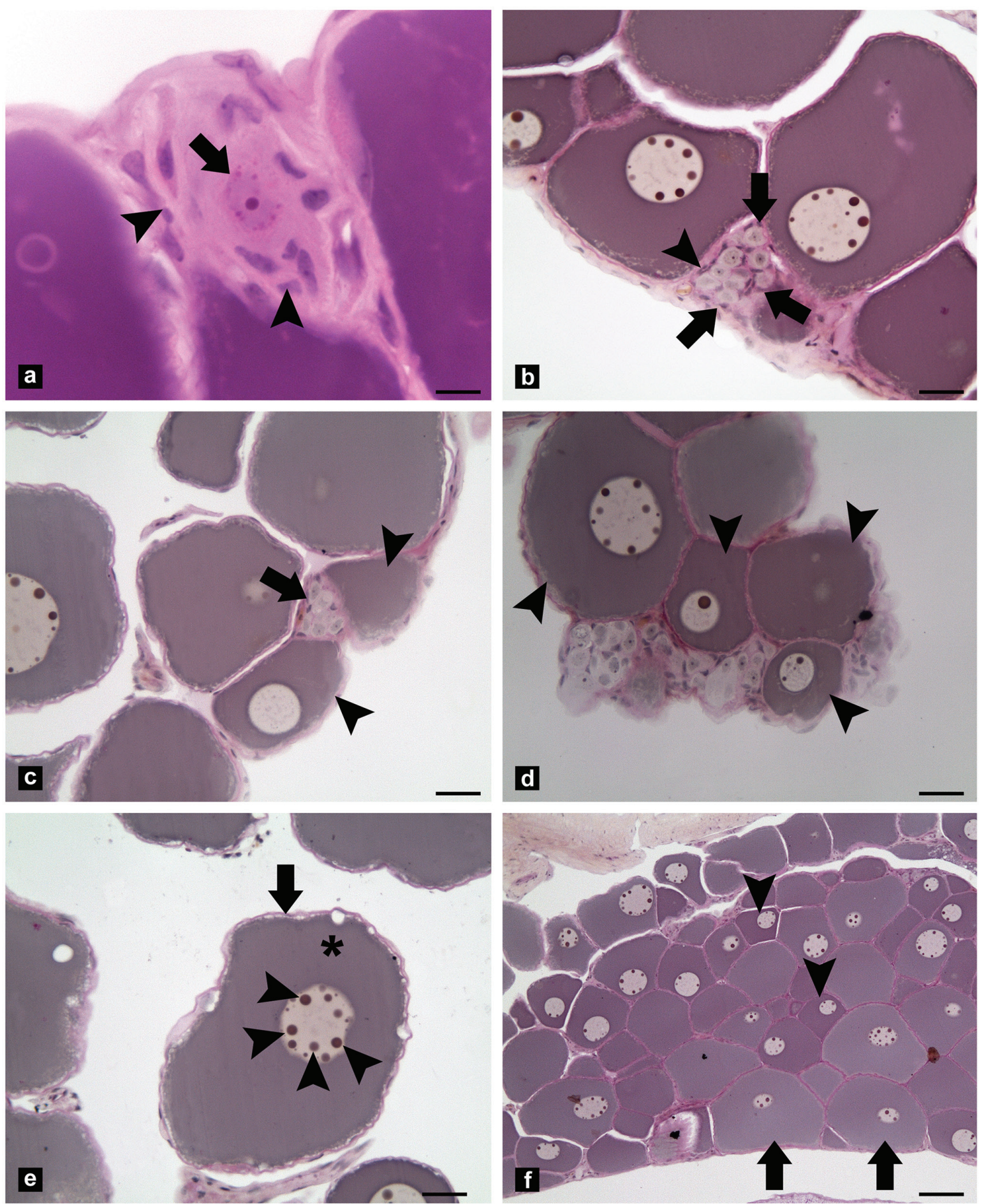

Fig. 1. Micrographs of the ovaries of Steindachneridion parahybae juveniles in captivity showing different germ cell types. a) scattered oogonia (arrow) within the germinal epithelium surrounded by prefollicle cells (arrowhead); b) proliferation of the oogonium gives rise to cell cluster that appears as small nests (delimited by the arrows), and are also surrounded by prefollicle cells (arrowhead); c) inside this nests, oogonia (arrow) enter into meiosis and progressively individualized by cells derived from the epithelium (prefollicle cells), and they become separated from nests, originating the oocytes (arrowhead); d) following the ovarian development, early primary growth or perinucleolar oocyte (arrowhead) is characterized by an enhancement of cytoplasm basophilia; e) Perinucleolar oocyte (asterisk) showing the thin follicular layer (arrow) and multiple nucleoli displaced in a perinuclear position (arrowhead); f) Perinucleolar stage in different size, showing in an initial (arrowhead) and advanced stage (arrow). Periodic-Acid-Schiff (PAS)/Weigert's Haematoxylin/Metanil Yellow staining. Scale bars: $10 \mu \mathrm{m}$ (a); $30 \mu \mathrm{m}$ (b,c,d,e); $400 \mu \mathrm{m}$ (f). 
Steindachneridion parahybae testes were surrounded by tunica albuginea, which invaginated forming incomplete septae that divided these organs into anastomosed seminiferous tubule. An epithelium constituted by germ cells and Sertoli cells was identified internally lined in these tubules (Fig. 2). In this case, testes were classified as unrestricted spermatogonial testes with anastomosing tubular type, composed by numerous tubules that contained the germinal compartment (Fig. 2a) and separated by interstitial tissue (Fig. 2a-b).

Spermatogonia (Fig. 2b) were the largest cells among the germ cell type inside the $S$. parahybae testes, and they were characterized by a well-developed central nucleus, prominent nucleoli and a clear but abundant cytoplasm. Isolated spermatogonia were observed surrounded by Sertoli cells (Fig. 2b). Moreover, spermatogonia were identified along the entire extension of seminiferous tubules. Spermatocytes and spermatids were positioned within the intratubular cysts (Fig. 2c). Spermatocytes (Fig. 2d) were smaller than spermatogonia cells, with clear cytoplasm, large central nucleus and they were organized as groups of rounded cells. Spermatids (Fig. 2e), another group of the cells inside the $S$. parahybae testes were identified. These cells were the smallest germ cell type inside the cysts (smaller than spermatocytes cells), completely spherical cell (with little cytoplasm) and a rounded nucleus (with compact chromatin). Following spermatogenesis process, several spermatocysts opened to release the spermatozoa (Fig. 2f) in the lumen of the duct. A greater concentration of spermatozoa was present in the tubular lumen of the S. parahybae testes. Additionally, unlike the ovaries, juvenile $S$. parahybae testes showed complete spermatogenic process.

Microscopically, the "IA" was also classified as unrestricted spermatogonial testes, anastomosing tubular type with numerous tubules (Fig. 3a) containing spermatogonia, spermatocytes, spermatids and spermatozoa, separated by the interstitial tissue (Fig. 3b). On the other hand, this same animal showed typical ovaries cells types (Fig. 3c), with oogonia and perinucleolar oocytes within these gonads (Fig. 3d).

Furthermore, the results of the present study also indicate that $S$. parahybae juvenile, when reared in captivity, the age of first maturation in male was during the first year of age (the males were already producing milt), unlike the females, because they only present signs of primary growth stage of oocytes (i.e., perinucleolar oocytes).

Conventional chromosome staining. Steindachneridion parahybae had a diploid number equal to 56 chromosomes with no morphological evidence of differentiated sex chromosomes or supernumerary chromosomes between males (Fig. 4a-b) and females (Fig. 4c-d). The karyotype formula was $4 \mathrm{~m}+22 \mathrm{sm}+12 \mathrm{st}+8 \mathrm{a}(\mathrm{FN}=104)$. Additionally, the "IA" (Fig. 4e-f) had also diploid number (56 chromosomes), same karyotype formula, and no morphological difference in chromosomes were observed among males, females and "IA" specimens.

\section{Discussion}

As showed by Ferraris (2007), the teleost order Siluriformes (Ostariophysi) that includes the largest number of living teleost fish species, contains 3.093 species popularly known as "catfish". Inside this order the family Pimelodidae is a large and diversified family of freshwater catfishes (Burgess, 1989). Additionally, Steindachneridion genus within the order Siluriformes, family Pimelodidae has six species described (see Garavello, 2005 for a review on Steindachneridion genus), and four species (S. amblyurum, S. doceanum, S. scriptum and S. parahybae) are listed in the Brazilian red list (Rosa \& Lima, 2008) and other two species ( $S$. melanodermatum and $S$. punctatum) do not have data about the risk of extinction. Therefore, the critically endangered species condition of $S$. parahybae (Honji et al., 2009) determined that the present study would be conducted with specimens raised in captivity in order to minimize possible impacts on natural populations, as well as previous studies with this species (Caneppele et al., 2009; Honji, 2011a, 2011b; Moraes Neto et al., 2011; Honji et al., 2012a, 2013, 2015).

Normal and abnormal development of fish gonadal tissue can be observed by histological changes throughout their development and reproductive cycle or at a specific time (as in this study); therefore, histology can be a powerful tools once the changes observed macroscopically do not sufficiently reflect the biological events that are taking place in the interior of the gonads. For this reason, gonad histological analysis allows a more precise assessment of the reproductive parameters of teleost fish species, since the method is more accurate (Hunter \& Macewicz, 1985; Honji et al., 2006). The histology of normal gonads of S. parahybae showed typical ovarian cells in captivity females (Honji, 2011a) and our research presents first results of histological analysis of the testes of this species. Additionally, using the basic definition, any gonads that contain both ovarian and testicular tissue in the same individual of gonochoristic species is classified as an intersex (ovotestes). So, this study has also provided the first detail histological evidence of intersex in a gonochoristic fish species inhabiting a Paraíba do Sul River Basin, whereas the histology of intersex fish showed cells from both sexes in one specimen.

Concerning the juvenile $S$. parahybae females, the gross gonads anatomy exhibited typical teleost ovaries with several germ cell types in different stage of development, most of these oocytes were at the previtellogenic stage (perinucleolar oocytes) and vitellogenic oocytes were not identified, indicating that the vitellogenin uptake into the oocytes has not started yet. Additionally, these ovarian maturation stages have been previously identified on preliminary studies in our laboratory (Honji, 2011a; Honji et al., 2012b, 2015), which focused on the oocyte development throughout the reproductive cycle in adult $S$. parahybae females, including individuals that were artificial induced to spawning in captivity. 

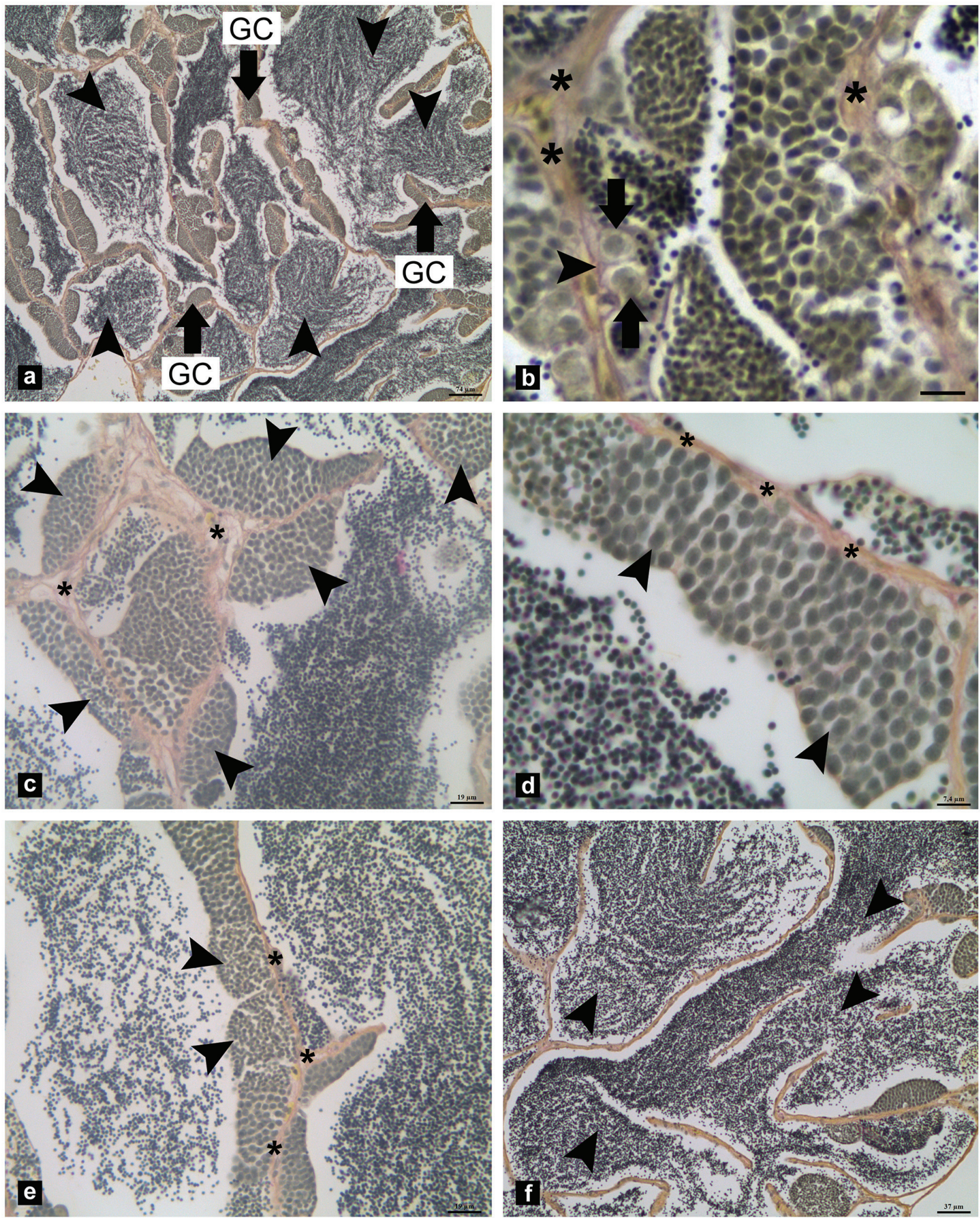

Fig. 2. Micrographs of the testes of Steindachneridion parahybae juveniles in captivity showing the different germ cell types. a) unrestricted spermatogonial testes with anastomosing tubular type, composed by numerous tubules (arrowhead), which contained the germinal compartment (GC, indicate with arrow) and separated by interstitial tissue; $b$ ) isolated spermatogonia cell (arrow) surrounded by Sertoli cells (arrowhead), separated by interstitial tissue (asterisk); c) many spermatocytes and spermatids within the cysts (arrowhead), separated by interstitial tissue (asterisk); d) cysts of spermatocytes (arrowhead), separated by interstitial tissue (asterisk); e) cysts of spermatids (arrowhead), separated by interstitial tissue (asterisk); f) many spermatozoa inside the tubular lumen (arrowhead). Periodic-Acid-Schiff (PAS)/Weigert's Haematoxylin/Metanil Yellow staining. Scale bars: $74 \mu \mathrm{m}$ (a); $37 \mu \mathrm{m}$ (f); $19 \mu \mathrm{m}$ (c,e); $14 \mu \mathrm{m}$ (b); $7.4 \mu \mathrm{m}$ (d). 

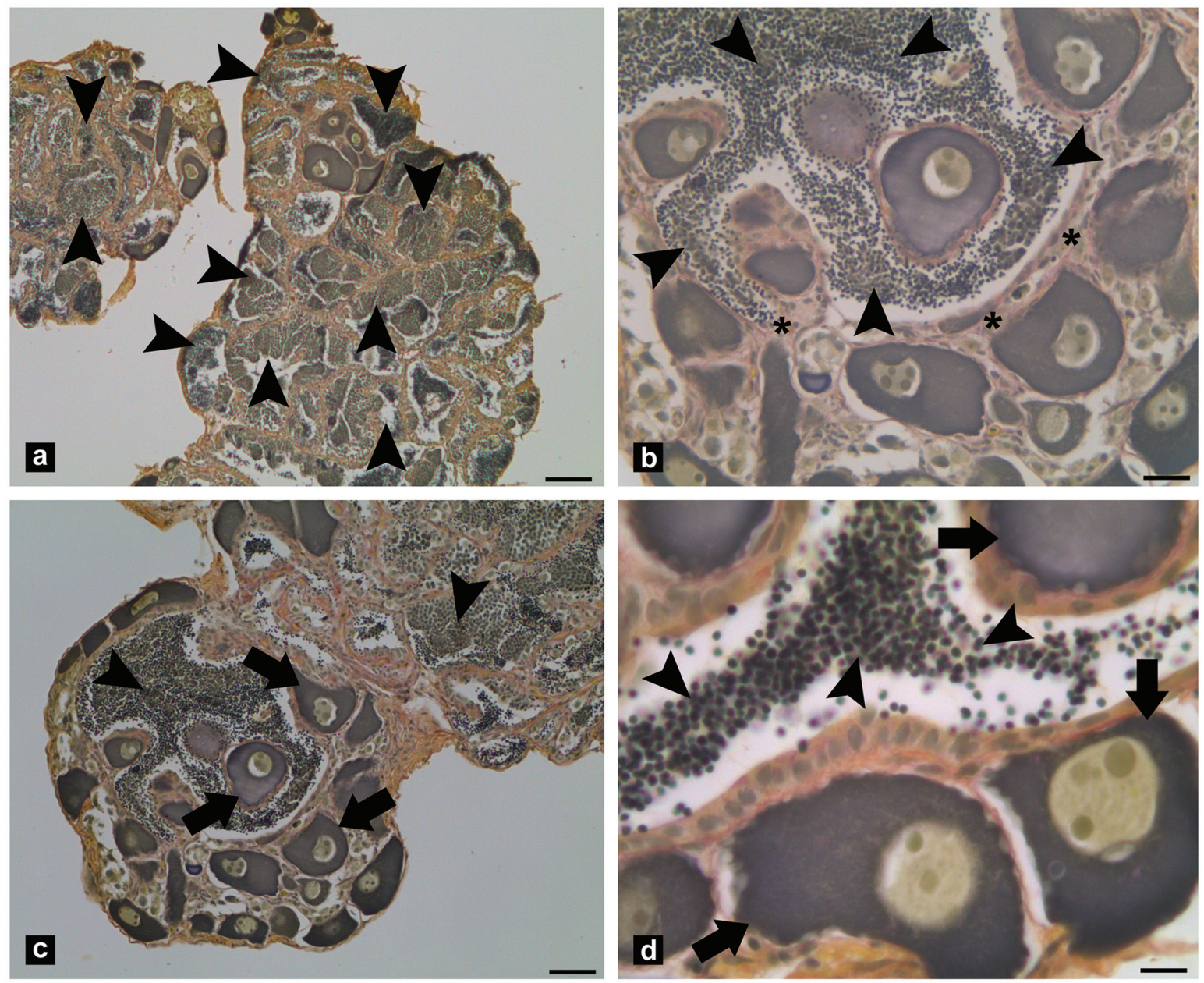

Fig. 3. Micrographs of the ovotestes of Steindachneridion parahybae juveniles in captivity showing the different germ cell types. a) unrestricted spermatogonial testes with anastomosing tubular type, composed by numerous tubules (arrowhead); b) many spermatozoa inside the tubular lumen (arrowhead), separated by interstitial tissue (asterisk); c) gonads section showing perinucleolar oocyte (arrow) close to testicular tissue (arrowhead), containing spermatozoa inside the duct and many intratubular cists; d) ovotestes showing perinucleolar oocyte (arrow) close to spermatozoa inside the duct (arrowhead). Periodic-Acid-Schiff (PAS)/Weigert's Haematoxylin/Metanil Yellow staining. Scale bars: $74 \mu \mathrm{m}$ (a); $19 \mu \mathrm{m}$ (b, d); $37 \mu \mathrm{m}$ (c).

By contrast, the gross anatomy of the testicular $S$. parahybae section differed clearly from the ovaries, showing normal mature testes. So, the present study has afforded the opportunity to observe the normal histological structures of the testes and described then. Although this study did not analyze the entire male reproductive cycle of $S$. parahybae, it was possible to distinguish easily the spermatogenesis process using criteria of size, shape, cytology and features of the nucleus of germ cells types, which were according to Brown-Peterson et al. (2002) and Schulz et al. (2010) classification. Gross testes histological morphology of $S$. parahybae indicates that the seminiferous tubules are intercommunicated and formed a network close to the testes periphery and throughout the whole gonads. These characteristic can be classified as "anastomosing tubular testes" (Grier, 1993; Parenti \& Grier, 2004), and as spermatogonia were distributed along the entire extension of S. parahybae seminiferous tubules, it can also be classified as "spermatogonial unrestricted", according to Grier et al. (1980). These features were similar to the pattern described for other Neotropical catfish species such as Conorhynchus conirostris (Lopes et al., 2004), Pseudoplatystoma fasciatum (Batlouni et al., 2006), Pimelodella vittata (Santos et al., 2010), Trachelyopterus striatulus (Santos et al., 2014), and others.

The spermatogenesis development in the testicular tissue of $S$. parahybae was practically complete since the majority of the ducts were filled with spermatozoa. This observation is in accordance with the sexual maturation dynamics of $S$. parahybae, considering that the present analyzes were performed in December, within the reproductive period of adult females of this species (Honji, 2011a; Honji et al., 2015). The presence of spermatozoa inside the duct testes, allow us to conclude that the males of this study were in the first testicular maturation, close to maturity, despite not having been observed spermiation when the abdominal region was slightly squeezed. 


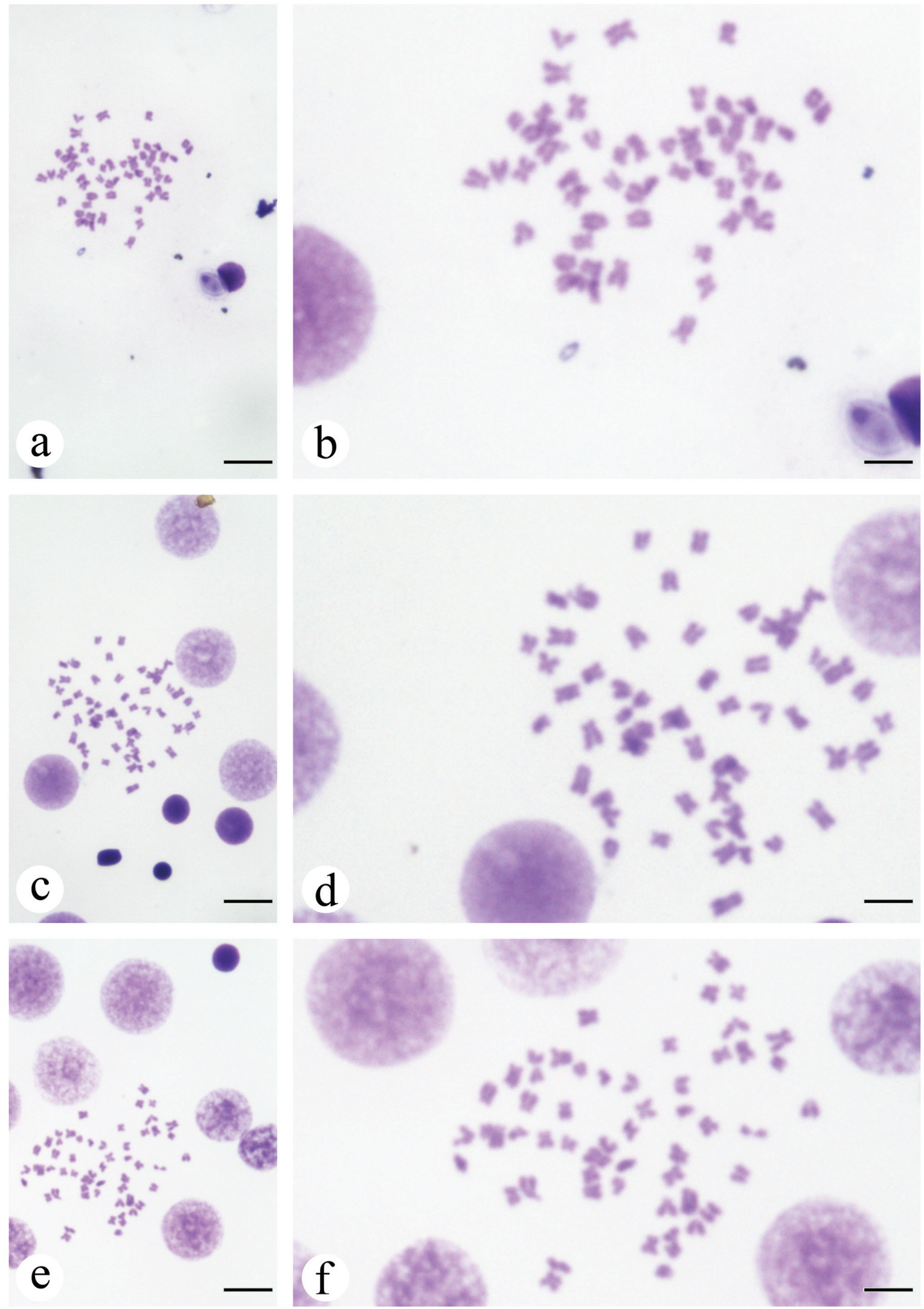

Fig. 4. Karyotype in Giemsa in male (a), detail in (b), in female (c), detail in (d) and in intersex animal (e), detail in (f) of Steindachneridion parahybae from Unidade de Hidrobiologia e Aquicultura, Companhia Energética de São Paulo. See the text for more information about karyotype characteristics. Scale bars: $37 \mu \mathrm{m}(\mathrm{a}, \mathrm{c}, \mathrm{e}) ; 7,4 \mu \mathrm{m}(\mathrm{b}, \mathrm{d}, \mathrm{f})$. 
Concerning the "IA" individual, occasionally this abnormal development of fish gonadal tissue is visible macroscopically but most often the gonads must be examined microscopically for detection. At the microscopy level, $S$. parahybae intersex gonads showed a great variation in the composition of female and male cells and their arrangement within the gonads. Although, the gonads showed macroscopic characteristic of ovaries, microscopically a large part of the gonads showed the composition of male cells. In "IA" sampled primary oocytes located within normally appearing seminiferous structure of testicular tissue were also revealed together. Therefore, this individual contained both male and female gonads, the ovarian part of the gonads was still young and filled with previtellogenic oocytes, whereas the male part contained mature gametes.

Even though the present study described for the first time, only a single individual under an intersex condition, the functional significance and the reproductive consequences of this anomaly in $S$. parahybae remain to be determined and/or suggesting that this species may be susceptible to endocrine disruption. Moreover, there is evidence that in some gonochoristic fish species low occurrence of intersex might also happen spontaneously (Bahamonde et al., 2013) or simple should be considered as an exceptional case. However, there are many studies reporting the increased occurrence of intersex in gonochoristic of teleost fish as a result of exposure to EDCs (Devlin \& Nagahama, 2002; Godwin, 2010; Bahamonde et al., 2013), even in other catfish species, for example, Pangasius nasutus, Heteropneustes fossilis, Clarias gariepinus (Rodriguez et al., 2012). Intersex condition can also be attributed to environmental conditions, i.e., thermolabile sex determination (Baras et al., 2000; Strüssmann \& Nakamura, 2002; Hurley et al., 2004). The region of $S$. parahybae distribution, the Paraíba do Sul River Basin, is impaired by the presence of chemicals that are used in agriculture (i.e., pesticides and herbicide and their metabolites) and/or other chemicals from domestic or industrial pollution, therefore we cannot exclude the possibility of intersex occurrence due to endocrine disruption. Additionally, S. parahybae has undergone intensive conservation aquaculture condition with artificial induced spawning (with hormonal manipulation, which interfere with hypothalamic-pituitary-gonads axis) and may have caused the unusual intersex condition found here. Moreover, there was no intentional sexual reverse practice at this fish farm. On the other hand, the discovery of the $S$. parahybae intersex occurred during examination of samples collected to study on "Environmental influences on the mechanisms of sex determination and differentiation in teleost fish" (Honji, 2011b); therefore, this intersex condition of $S$. parahybae cannot rule out the possibility that environment factors may have caused the sexual "abnormality".

According to Devlin \& Nagahama (2002) and Strüssmann \& Nakamura (2002), sex determination and sex differentiation in teleost fish is a plastic process with respect to evolutionary patterns observed among families and genera, and within individuals it is subject to influenced by environment factors. These influences can affect both somatic and germ cells within the primordial gonads, including the action of genetic (Hattori et al., 2007), environmental (Strüssmann \& Nakamura, 2002), behavior and physiological factors (Devlin \& Nagahama, 2002). Therefore, in the present case of $S$. parahybae intersex, the origin of factors that could lead to the observed intersex gonads remains undetermined and insight into the initial events that eventually lead a germ cell within the primordial gonads to become an oogonium, a spermatogonium or both, should be also conducted.

Since 2003, our group has been working with $S$. parahybae within a conservation program undertaken by CESP (CESP, 2006a), when the first artificial breeding was achieved (Caneppele et al., 2009), and subsequent monitoring of the juveniles until maturation showed, for the first time, which $S$. parahybae male become mature at one year, unlike the $S$. parahybae females, which in the present study did not show signs of the first maturity in the first year of life. These females showed only signs of primary growth stage of oocytes. Additionally, morphological indices such as GSI and HSI have been used as quantitative indices of physiological conditions of individuals (Vazzoler, 1981, 1996). The application of these indices, analyzed together with the gonads maturation of the reproductive cycle, total length and/or seasonal time (summer, autumn, winter and spring) are important to detect the spawning season due to weigh changes during reproductive process and/or may be indicative of the dynamics of energetic substrates in the gonads and liver (Vazzoler, 1981, 1996; Marcano et al., 2007). As the present study did not analyze these indices over seasonal time or reproductive cycle or with metabolic data of $S$. parahybae, we cannot draw any conclusion. However, GSI values changes during reproductive cycle of adult $S$. parahybae were already described by Honji et al. (2015).

Despite the Siluriformes order is a large and diversified group as cited above, according to Oliveira \& Gosztonyi (2000), only about $13 \%$ of this order was karyotyped. For the Steindachneridion genus these data is even scarcer, because only two species had their karyotype studied, the $S$. scriptum (cited as $S$. scripta) and the $S$. parahybae (respectively Swarça et al., 2005 and Moraes Neto et al., 2011). The karyotype data found in the present study for S. parahybae corroborate the data obtained by Moraes Neto et al. (2011) for the same species; however, these authors analyzed other lot of breeding of the CESP. Both studies showed a diploid number of 56 chromosomes with $\mathrm{FN}=104$ for $S$. parahybae and the found karyotype macrostructure does not differ from that seen in others Pimelodidae species (Oliveira \& Gosztonyi, 2000; Swarça et al., 2005; Moraes Neto et al., 2011), supporting the hypothesis that this modal number is verified in most catfish families (Oliveira \& Gosztonyi, 2000).

In conclusion, this cytogenetic and histological study is the first report on the presence of intersex in the endangered S. parahybae juvenile from Paraíba do Sul River Basin, as well as intersex fish at CESP conservation fish farm. Our data, together with the findings previously described by Caneppele 
et al. (2009) and Honji et al. (2012a, 2013, 2015), will be important to improve specific conservation management for this endangered catfish by providing biological tools to conservation biologist. This information, resulting from field- and laboratory-based researches, is also essential to ensure the success of $S$. parahybae controlled breeding programs in this basin, and the establishment of a more effective re-introduction program, as well as an investigation of its potential for fish farming and also could be proposed as a new sentinel species in the Paraíba do Sul River Basin.

\section{Acknowledgements}

The authors would like to thank Companhia Energética de São Paulo (CESP) for providing the fish farm facilities. The authors are also grateful to Dra. Lurdes F. A. Toledo, Dr. Ricardo S. Hattori and Mr. Carlos E. Lopes (Departamento de Genética e Biologia Evolutiva, Instituto de Biociências, Universidade de São Paulo), for offering their support and laboratory use for cytogenetic analysis. This work was supported by the following grants: FAPESP 2008/576870, 2011/50288-5 and 2012/50918-1 (Fundação de Amparo à Pesquisa do Estado de São Paulo) and IFS A/5351-1 (International Foundation for Science).

\section{References}

Bahamonde, P. A., K. R. Munkittrick \& C. J. Martyniuk. 2013. Intersex in teleost fish: are we distinguishing endocrine disruption from natural phenomena?. General and Comparative Endocrinology, 192: 25-35.

Baras, E., C. Prignon, G. Gohoungo \& C. Méalard. 2000. Phenotypic sex differentiation of blue tilapia under constant and fluctuating thermal regimes and its adaptive and evolutionary implications. Journal of Fish Biology, 57: 210-223.

Batlouni, S. R., E. Romagosa \& M. I. Borella. 2006. The reproductive cycle of male catfish Pseudoplatystoma fasciatum (Teleostei, Pimelodidae) revealed by changes of the germinal epithelium: an approach addressed to aquaculture. Animal Reproduction Science, 96: 116-132.

Beardmore, J. A., G. C. Mair \& R. I. Lewis. 2001. Monosex male production in finfish as exemplified by tilapia: applications, problems, and prospects. Aquaculture, 197: 283-301.

Behmer, O. A., E. M. C. Tolosa \& A. G. F. Neto. 1976. Manual de técnicas para histologia normal e patológica. São Paulo, São Paulo Livraria Editora, 241p.

Brown-Peterson, N. J., H. J. Grier \& R. M. Overstreet. 2002. Annual changes in germinal epithelium determine male reproductive classes of the cobia. Journal of Fish Biology, 60: 178-202.

Burgess, W. E. 1989. An atlas of freshwater and marine catfishes: a preliminary survey of the Siluriformes. Neptune City, TFH Publications, 784p.

Caneppele, D. 2007. Peixes. Pp. 91-103. In: Ferreira, P. C. (Ed). Biologia e a geografia do Vale do Paraíba: trecho paulista. São José dos Campos, IEPA.

Caneppele, D., R. M. Honji, A. W. S. Hilsdorf \& R. G. Moreira. 2009. Induced spawning of the endangered Neotropical species Steindachneridion parahybae (Siluriformes: Pimelodidae). Neotropical Ichthyology, 7: 759-762.
CESP (Companhia Energética de São Paulo). 2006a. 40 peixes do Brasil: CESP 40 anos. Rio de Janeiro, Doiis, 208p.

CESP (Companhia Energética de São Paulo). 2006b. Formação de um banco de germoplasma da ictiofauna ameaçada da Bacia do Rio Paraíba do Sul. CESP/ANEEL (0061-017/2006). Available from: http:/www.cesp.com.br/portalCesp/portal.nsf/V03.02/ Inovacao_P\&DProjeto05?OpenDocument (Date of access - 01 June 2015).

Devlin, R. H. \& Y. Nagahama. 2002. Sex determination and sex differentiation in fish: an overview of genetic, physiological, and environmental influences. Aquaculture, 208: 191-364.

FAO (Food and Agriculture Organization of the United Nations). 2010. The state of world fisheries and aquaculture, FAO Rome, 197p. Available from: http://www.fao.org/docrep/013/i1820e/ i1820e.pdf (Date of access - 01 May 2016).

Ferraris, C. J. 2007. Checklist of catfishes, recent and fossil (Osteichthyes: Siluriformes), and catalogue of siluriform primary types. Auckland, Magnolia Press. (Zootaxa, n. 1418, 628p.).

França, G. F., H. J. Grier \& I. Quagio-Grassiotto. 2010. A new vision of the origin and the oocyte development in the ostariophysi applied to Gymnotus sylvius (Teleostei, Gymnotiformes). Neotropical Ichthyology, 8: 787-804.

Garavello, J. C. 2005. Revison of genus Steindachneridion (Siluriformes: Pimelodidae). Neotropical Ichthyology, 3: 607623.

Godwin, J. 2010. Neuroendocrinology of sexual plasticity in teleost fishes. Frontiers in Neuroendocrinology, 31: 203-216.

Gold, J. R., Y. C. Li, N. S. Shipley \& P. K. Powers. 1990. Improved methods for working with fish chromosomes with a review of methaphase chromosome banding. Journal of Fish Biology, 37 : 563-575.

Grier, H. J. 1993. Comparative organization of Sertoli cells including the Sertoli barrier. Pp. 703-739. In: Russel, L. D. \& M. D. Griswold (Eds.). The Sertoli Cell. Clearwater, Cache River Press.

Grier, H. J., J. R. Linton, J. F. Leatherland \& V. L. De Vlaming. 1980. Structural evidence for two different testicular types in teleost fishes. American Journal of Anatomy, 159: 331-345.

Hattori, R. S., R. J. Gould, T. Fujioka, T. Saito, J. Kurita, C. A. Strüssmann, M. Yokota \& S. Watanabe. 2007. Temperaturedependent sex determination in Hd-rR medaka Oryzias latipes: gender sensitivity, thermal threshold, critical period, and DMRT1 expression profile. Sexual Development, 1: 138-146.

Hilsdorf, A. W. S. \& M. Petrere Jr. 2002. Conservação de peixes na bacia do rio Paraíba do Sul. Ciência Hoje, 30: 62-65.

Honji, R. M. 2011a. Controle do eixo hipotálamo-hipófisegônadas do surubim do Paraíba Steindachneridion parahybae (Siluriformes: Pimelodidae) em relação ao ciclo reprodutivo e à reprodução induzida em cativeiro. Unpublished $\mathrm{Ph}$. D. Dissertation, Universidade de São Paulo, São Paulo, 300p.

Honji, R. M. 2011b. Influências ambientais sobre os mecanismos de determinação e diferenciação sexual em peixes teleósteos, FAPESP (2011/50288-5). Available from: http://www. bv.fapesp.br/pt/bolsas/117562/influencias-ambientais-sobreos-mecanismos-de-determinacao-e-diferenciacao-sexual-empeixes-teleoste/ (Data of access - 01 June 2016).

Honji, R. M., A. M. Vaz-dos-Santos \& C. L. D. B. RossiWongtschowski. 2006. Identification of the stages of ovarian maturation of the Argentine hake Merluccius hubbsi Marini, 1933 (Teleostei: Merlucciidae): advantages and disadvantages of the use of the macroscopic and microscopic scales. Neotropical Ichthyology, 4: 329-337. 
Honji, R. M., D. Caneppele, A. W. S. Hilsdorf \& R. G. Moreira. 2009. Threatened fishes of the world: Steindachneridion parahybae (Steindachner, 1877) (Siluriformes: Pimelodidae). Environmental Biology of Fishes, 85: 207-208.

Honji, R. M., C. E. Tolussi, P. H. Mello, D. Caneppele \& R. G. Moreira. 2012a. Embryonic development and larval stages of Steindachneridion parahybae (Siluriformes: Pimelodidae) implications for the conservation and rearing of this endangered Neotropical species. Neotropical Ichthyology, 10: 313-327.

Honji, R. M., D. Caneppele, M. Pandolfi \& R. G. Moreira. 2012b. Studies on the brain-pituitary-ovaries axis of Steindachneridion parahybae (Siluriformes: Pimelodidae) females when reproductive migration is blocked. $7^{\text {th }}$ International Symposium of Fish Endocrinology, Abstract, 1(1): 161-161.

Honji, R. M., D. Caneppele \& R. G. Moreira. 2013. Caracterização macroscópica das gônadas durante reprodução induzida em cativeiro do surubim-do-Paraíba. Pesquisa Agropecuária Brasileira. 48: 1110-1114.

Honji, R. M., D. Caneppele, M. Pandolfi, F. L. Lo Nostro \& R. G. Moreira. 2015. Gonadotropins and growth hormone family characterization in an endangered siluriform species Steindachneridion parahybae (Pimelodidae): relationship with annual reproductive cycle and induced spawning in captivity. The Anatomical Records, 298: 1644-1658.

Hunter, J. R. \& B. J. Macewicz. 1985. Rates of atresia in ovary of captive and wild northern anchovy, Engraulis mordax. Fishery Bulletin, 83: 119-136.

Hurley, M. A., P. Mattiessen \& A. D. Pickering. 2004. A model for environmental sex reversal in fish. Journal of Theoretical Biology, 227: 159-165.

Levan, A., K. Fredga \& A. A. Sandberg. 1964. Nomenclature for centromeric position on chromosomes. Hereditas, 52: 201-220.

Lopes, D. C. J. R., N. Bazzoli, M. F. G. Brito \& T. A. Maria. 2004. Male reproductive system in the South American catfish Conorhynchus conirostris. Journal of Fish Biology, 64: 14191424.

Marcano, D., E. Cardillo, C. Rodriguez, G. Poleo, N. Gago \& H. Y. Guerrero. 2007. Seasonal reproductive biology of two species of freshwater catfish from the Venezuelan floodplains. General and Comparative Endocrinology, 153: 371-377.

Moraes Neto, A., M. Silva, D. A. Matoso, M. R. Vicari, M. C. Almeida, M. J. Collares-Pereira \& R. F. Artoni. 2011. Karyotype variability in neotropical catfishes of the family Pimelodidae (Teleostei: Siluriformes). Neotropical Ichthyology, 9: 97-105.

Mylonas, C. C., A. Fostier \& S. Zanuy. 2010. Broodstock management and hormonal manipulations of fish reproduction. General and Comparative Endocrinology, 165: 516-534.

Navas, C. A. 2008. Effects of global climate change on the Brazilian fauna: a conservation approach, FAPESP (2008/57687-0). Available from: http://www.fapesp.br/pfpmcg/pfpmcg_iannini. pdf (Date of access - 01 June 2016).

Nelson, J. S. 2006. Fishes of the World. New York, John Wiley \& Sons Inc., 624p.

Nolan, M., S. Jobling, G. Brighty, J. P. Sumpter \& C. R. Tyler. 2001. A histological description of intersexuality in the roach. Journal of Fish Biology, 58: 160-176.

Oliveira, C. \& A. E. Gosztonyi. 2000. A cytogenetic study of Diplomystes mesembrinus (Teleostei, Siluriformes, Diplomystidae) with a discussion of chromosome evolution in siluriforms. Caryologia, 53: 31-37.
Pandian, T. J. \& S. G. Sheela. 1995. Hormonal induction of sex reversal in fish. Aquaculture, 138: 1-22.

Parenti, L. R. \& H. J. Grier. 2004. Evolution and phylogeny of gonadal morphology in bony fishes. Integrative and Comparative Biology, 44: 333-348.

Pearse, A. G. E. 1985. Histochemistry: theoretical and applied. Churchill Livingstone, London, 614p.

Pisano, E., C. Ozouf-Costaz, F. Foresti \& B. G. Kapoor. 2007. Fish cytogenetics. Enfield, Science Publishers), 518p.

Quintero-Hunter, I., H. J. Grier \& M. Muscato. 1991. Enhancement of histological detail using metanil yellow as counterstain in periodic acid Schiff's hematoxylin staining of glycol methacrylate tissue sections. Biotechnic \& Histochemistry, 66: 169-172.

Rodriguez, J. N., J. Slembrouck, J. Subagja \& M. Legendre. 2012. Intersex in a cultured specimen of the Indo-Malay catfish, Pangasius nasutus (Bleeker, 1863). Journal of Applied Ichthyology, 28: 284-286.

Rosa, R. S. \& F. C. T. Lima. 2008. Peixes. Pp. 9-275. In: Machado, A. B. M., G. M. Drummond \& A. P. Paglia (Eds.). Livro vermelho da fauna brasileira ameaçada de extinção. Brasília, MMA. (Biodiversidade 19, v. 2).

Santos, J. E., V. C. Veloso-Júnior, D. A. Andrade Oliveira \& R. E. S. Hojo. 2010. Morphological characterization of the testis of the catfish Pimelodella vittata (Lütken, 1874). Journal of Applied Ichthyology, 26: 942-945.

Santos, M. L., N. G. Sales, F. P. Arantes, T. C. Pessali, N. Bazzoli \& J. E. Santos. 2014. Anatomical and histological organization of the testes of the inseminating catfish Trachelyopterus striatulus (Steindachner, 1877) (Siluriformes: Auchenipteridae). Anatomia, Histologia, Embryologia, 43: 310-316.

Schulz, R. W., L. R. De França, J. J. Lareyre, F. LeGac, H. ChiariniGarcia, R. H. Nóbrega \& T. Miura. 2010. Spermatogenesis in fish. General and Comparative Endocrinology, 165: 390-411.

Strüssmann, C. A. \& M. Nakamura. 2002. Morphology, endocrinology, and environmental modulation of gonadal sex differentiation in teleost fishes. Fish Physiology and Biochemistry, 26: 13-29.

Swarça, A. C., A. S. Fenocchio, M. M. Cestari \& A. L. Dias. 2005. Karyotype divergence among populations of giant catfish Pseudoplatystoma corruscans (Teleostei: Pimelodidae) indicates higher species diversity. Ichthyology Exploration Freshwater, 16: 325-330.

Tyler, C. R. \& S. Jobling. 2008. Roach, sex, and gender-bending chemicals: the feminization of wild fish in English rivers. Bioscience, 58: 1051-1059.

Vazzoler, A. E. A. M. 1981. Manual de métodos para estudos biológicos de populações de peixes: reprodução e crescimento. Brasília, CNPq, 108p.

Vazzoler, A. E. A. M. 1996. Biologia da reprodução de peixes teleósteos: teoria e prática. Maringá, EDUEM, 169p.

Volff, J. N. 2005. Genome evolution and biodiversity in teleost fish. Heredity, 94: 280-294.

Zar, J. H. 2010. Biostatistical analysis. New Jersey, Prentice Hall, 960 p. 